\title{
Learner identity in EFL: An analysis of digital texts of identity in higher education
}

\author{
María Dolores García-Pastor \\ maria.d.garcia@uv.es \\ Faculty of Education - Universitat de València (GIEL)
}

\begin{abstract}
This study explores learner identity (LI) in digital texts of identity (DTI) produced by college learners in English as a foreign language (EFL). In so doing, it aims to shed light on learners' connections of their learning experiences across time and settings, and their impact on the various learner identities that form their LI. It also intends to elucidate how learners construct powerful learner identities in and through their digital discourses. To this end, 51 DTI were collected and scrutinized, following studies on LI, critical and poststructuralist discourse analysis, "thematic" and "dialogic/performative" analysis within narrative research, and Kress and van Leeuwen's (2006) framework for the analysis of images. Learners established connections between their family and daily life spaces, school, and the foreign language community that account for, and shape their construction of their identities as learners in general, and language learners in particular. Students also empowered themselves by identifying with an intercultural speaker, using authority claims, and, in general, enhancing their authoritativeness in and through their texts. These findings underscore the potential of DTI to reinforce learners' identities, and create more equitable learning spaces.
\end{abstract}

\section{Keywords}

EFL learning and teaching; digital communication; identity; learner identity 


\section{Introduction}

Identity and its relation to learning has been of central concern to scholars in educational psychology and other disciplines (Coll \& Falsafi, 2010; Esteban-Guitart \& Saubix, 2013; EstebanGuitart \& Moll, 2014; Wortham, 2006). In language education, researchers' attention to the relationship between identity and language learning traces back to Bonny Norton's 1995 seminal paper. However, there has been "an explosion of interest" in such relationship more recently (Norton \& Toohey, 2011, p. 413) and research on identity has exponentially grown with this construct featuring prominently in articles, monographs and edited collections in this field and related others like applied linguistics (cf., e.g., Mackey, 2015; Norton, 2013; Preece, 2016). This is unsurprising, if we consider the current view of education "as a process of "person shaping" designed to extend and perhaps in some ways modify learners' identity" (Little \& Erickson, 2015, p. 121) and the idea that language is a vehicle for learners' identity construction (Norton, 2013). Additionally, learner identity is a key concept to understand other identities students build, since learning is the means by which we come to participate in different communities of practice and construct diverse identities as community members (Wenger, 1998). Yet, in spite of its relevance, learner identity is still under-researched and "the process of becoming and changing as a learner is either neglected or not ascribed much significance" (Coll \& Falsafi, 2010, p. 218).

On the other hand, the spread and use of Information and communication technologies (ICTs) has contributed to shape and transform language, identity, learning and their relationship. Digital communication provides learners with multiple semiotic resources for meaning making, which accounts for the emergence of new genres and modes of social interaction (Jones \& Hafner, 2012), e.g., the digital story telling genre in educational contexts (Gregori-Signes \& Pennock-Speck, 2012). In that sense, it also offers students opportunities for genuine learning experiences, since, inter alia, it provides them with new contexts for using and developing literacy different from traditional formal instruction settings. This may not only enhance learners' investment in their learning process (cf. Norton, 1995), but may facilitate social interaction to those students who experience face-to-face communication as highly threatening (Darvin, 2016).

By transforming language and its use, the digital has also altered identity, since it affords learners new pathways to multiple identities that enable them to connect their learning experiences across time and settings, and assert themselves as legitimate speakers in a variety of online and offline spaces (Darvin, 2016; Darvin \& Norton, 2015; Esteban-Guitart et al., forthcoming). These affordances of technology-mediated communication have brought about new conceptualizations of learning that in turn affect learners' construction of identities as well as their skills, literacies and cognitive and learning processes (Rosen, 2010; Thorne et al., 2015). How digital communication impacts on all these different aspects of learning is an unresolved question that research into digital and learning is currently intending to address (Darvin, 2016; Thorne et al., 2015).

This study is in line with this research agenda, since it aims to modestly contribute to shedding light on the construct of learner identity in EFL learning by attempting to determine: a) how EFL learners link their different learning experiences across time and spaces in digital texts of identity (DTI) produced in this language; b) how the connections they establish influence the way they build their identities as learners; and c) how they foreground their agency in some settings, so that they build powerful identities in and through their discourses (Darvin \& Norton, 2014; Fong et al., 2016; Menard-Warwick, 2007; Norton, 1995; Thorne \& Black, 2011; Yi, 2007; etc.). 
In our view, attending to these queries necessarily entails considering the semiotic ${ }^{1}$ and discursive resources and strategies learners use to build their learner identities in and through their texts. DTI are suitable for this purpose, since they are digital artifacts that students produce as a result of having invested their identities in them (Cummins \& Early, 2011). Therefore, they not only allow for the exploration of students' use of multimodal tools for meaning making like any other technology-mediated space or genre, but they facilitate such analysis with regards to identity.

\section{Learner identity in language education: a focus on digital discourses}

Within the field of language education the terms "identity", which mostly refers to a learner's identity as a second or foreign language (L2/FL) learner, and "L2 self" have often been used interchangeably. However, it must be made clear that the former refers to the social appraisal of the self in language learning situations, whilst the latter may be defined as the organised dynamic system that encompasses all the beliefs, cognitions, emotions, motives and processes related to and concerning oneself as L2 learner (cf. Mercer, 2014). These do not exclusively inhabit in the learner's mind, but are "intimately connected to the physical through actions, behaviours and physical senses, thereby uniting body, mind and environment" (ibid. 164). A learner's identity as a language learner can then be thought of as the social enactment of their linguistic self, which is also symbolic or mediated by signs and symbols; reflexive, since it allows for the recognition of the linguistic self and such self in practice; and a source of motivation for action, as it organises communicative behaviour and purposeful meaning making in the L2/FL (cf. Esteban-Guitart \& Moll, 2014). Both concepts, however, were incepted within motivation research in second language acquisition with regards to the sociological construct of investment (identity) and the psychological construct of motivation (L2 self) (see Dörnyei, 2009; Norton, 1995). They are also characterised by their dynamic and on-going nature and are mediated by language.

Although identity in general is a complex and vague construct, whose conceptualization is contingent upon the researcher's theoretical position (Esteban-Guitart \& Moll, 2014), a learner's identity in L2/FL learning has been generally understood as "the different subjectivities and subject positions they inhabit or have ascribed to them within particular social, historical, and cultural contexts" (Block, 2013, p. 18). More specifically, it consists of the manner in which the learner understands their relationship to the target language, other languages and the world; how such relationship is constructed across time and space; and how they understand possibilities for the future (cf. Norton, 1995, 2010b, 2013, 2014). This accounts for the nature of this construct as "a diverse, dynamic, often contradictory, multiple rather than unitary concept" (García-Pastor, 2017, p. 39), which the learner jointly constructs, negotiates, rejects or strives for in and through their interactions with other social agents in typically inequitable social contexts (Block, 2010, 2013; Norton, 2010a, 2010b, 2013, 2014; Norton \& Toohey, 2011). Underlying this depiction of identity is a poststructuralist perspective on social reality and second language learning that contrasts with essentialist positions, in which identity is clearly delimited, fixed, coherent and is expected to be similar among individuals (Baxter, 2016). This perspective corresponds with the default approach to the study of identity in language education (Baxter, 2016; Block, 2013; García-Pastor, 2017, 2018; Norton, 2013, 2014; Norton \& Toohey, 2011).

\footnotetext{
${ }^{1}$ In this study we are mainly referring to images.
} 
In spite of the different poststructuralist views of identity in the field (see Norton, 2014; Norton \& Toohey, 2011), these divergent positions have their philosophical origins in postmodernism, and share an understanding of language as a means for meaning-making and the place where identities are constructed and performed (Baxter, 2016). Poststructuralist theories of identity in language education also see the language learner situated within the larger social world, in which they are able to participate by choosing diverse positions from which to speak, listen, read or write in the $\mathrm{L} 2 / \mathrm{FL}$, thereby experiencing enhanced possibilities for social interaction and agency. On the other hand, the learner is sometimes unable to partake in social life due to linguistic and societal constrains that impose certain subject positions on them and impede their attainment of desirable identities in the target language. These constraints therefore reflect how power is distributed across formal and informal language learning contexts, and how it affects learners' identity construction and relationships with target language speakers. More specifically, they illustrate learners' access to the practices and resources of specific language learning settings and the effect of such access on their construction of identity. Finally, how a learner envisions future identities in their learning of L2/FL is also an integral part of his/her language learner identity (Norton, 2014; Norton \& Toohey, 2011).

Technology-mediated spaces have become relevant sites for the examination of learners' identities in L2/FL learning due to the significance and transformational power of ICTs in language education. ICTs not only facilitate access and exposure to authentic and updated linguistic and cultural materials (Zhao, 2003; González-Lloret \& Ortega, 2014), which together with comprehensible input are necessary for L2/FL learning (Krashen, 1982), but are also more likely to attend to learners' diverse learning styles and differences than non-digitally-based instruction (Chapelle \& Heift, 2009), partly due to their multimodal nature. Multimodality also contributes to the creation of stronger memory links that may enhance students' linguistic learning meaningfully (Zhao, 2003), and can raise their motivation, since they are more open to risk taking and creative expression while using language and semiotic means to make meaning (González-Lloret \& Ortega, 2014). Additionally, ICTs provide valuable opportunities for engaging in authentic communication in the target language, which is essential for successful language learning (Swain, 1993) and promoting meaningful learning. This may be achieved through interactions with the computer or with remote audiences that promote more equal and better participation, favouring students' production in the L2/FL (e.g., Jin, 2013; Klimanova \& Dembovskaya, 2013). The capacity for ICTs to offer instant and individualised feedback is also unquestionable with the development of automatic speech recognition technology (Zhao, 2003) and the emergence of increasingly sophisticated grammar and spell checkers, computer programs and applications that track, analyse and correct students' errors in writing or speech (e.g., write and improve by Cambridge) ${ }^{2}$.

Most importantly, ICTs have revolutionised and redefined the concept of literacy (Cope \& Kalantzis, 2015) and what it means to be literate in a second or foreign language (Norton, 2010a, 2010b; Norton \& Toohey, 2011). Literacy is intimately related to the construct of identity in general, and learner identity in particular, since a) in practicing any form of literacy, the individual is instantiating a particular social identity and membership in a specific social group (Ivanič, 1998; Lam, 2000), and b) a learner's engagement in written, oral or multimodal textual practices in L2/FL both for comprehension and production is also an engagement in acts of identity (Norton, 2010a, 2010b). Thus, Lam (2000) examined a Chinese immigrant teenager's written correspondence with a transnational group of peers on the Internet to show how his developing literacy in L2 was related to his construction of identity as a proficient English user in the World Wide Web based on

\footnotetext{
${ }^{2}$ http://www.cambridgeenglish.org/learning-english/free-resources/write-and-improve/.
} 
certain strategies he used to position himself in his writing. In exploring the out-of-school literacy practices of an L1 Korean ninth grader learning English, Yi (2007) evinced how such practices contributed to her biliterate development, and her crafting of an identity as a competent writer, which counterbalanced on occasion a negative identity as an English as a second language writer.

Similarly, Chen (2013) scrutinized the literacy practices of two multilingual writers on a social networking site to illustrate how they explored and reappropriated symbolic resources afforded by such context as they aligned themselves with particular collective and personal identities. Thorne and Black (2011) demonstrated that Internet-mediated spaces serve as catalysts for evoking and performing functional identities in L2 Spanish, French and English learners, and that composing and posting texts in such environments contribute to students' language development, which is interrelated with the creation of these identities. Along these lines, Fong et al. (2016) evinced how ESOL learners positioned themselves as good students and competent English learners in an online chat. These studies therefore attest to the contribution of digitally mediated literacy practices to the learner's linguistic development and their construction of an identity as competent subjects, who do not fear failure, embarrassment or losing face in their use of the L2/FL (see Darvin, 2016; González-Lloret \& Ortega, 2014). This does not mean, however, that technology-mediated interaction is unproblematic (see, e.g., Thorne \& Black, 2007); rather, that digital communication offers students opportunities for constructing their learner identities in new ways that enable them to enhance the value of their linguistic and cultural capital in the L2/FL.

\section{Digital texts of identity}

DTI are digital stories (DS) that afford learners the possibility to build multiple identities, which can help them have a "voice" in the L2/FL (García-Pastor, 2017, 2018). As established in the digital storytelling literature, digital stories (DS) help learners to share their voices and views both in noninteractive and open and interactive ways (Oskoz \& Elola, 2016). These have yielded two general types of DS, i.e., non-interactive DS with a pre-established traditional linear narrative structure, and interactive DS with a non-linear flexible narrative structure that even the audience can change (Rodríguez-Illera \& Londoño-Monroy, 2009). However, DS have also been distinguished according to their eminently social or personal character (Gregori-Signes \& Pennock-Speck, 2012), their narrative, descriptive, conversational, expository, or argumentative style (Londoño-Monroy, 2012), and their topic (Lambert, 2010), inter alia. Thus, DS can focus on an important person, event or a place in our lives, the things we do and like, our learning experiences, our relationships with others, and ourselves, that is, our identity and the community we belong to (ibid.). DTI are DS about the latter, which illustrate a hybrid autobiographical genre that takes the shape of memoires and personal recounts or narratives (García-Pastor, 2017).

Although DTI are a specific kind of DS, both have a different genesis. DS mainly originate from the work developed at the Centre for Digital Storytelling (CDS) in California (StoryCenter from 2015). By contrast, DTI and their non-digital counterparts emerged as part of a large project conducted in schools within the Greater Toronto Area to support the development of literacy in English language learners (ELL), and students from marginalized social groups both in English and their L1 (Cummins 2006; Cummins et al. 2005a; Cummins et al., 2015). Therefore, identity texts in general (digital and non-digital) are bilingual or multilingual artifacts that students produce in "written, spoken, signed, visual, musical, dramatic, or combinations in multimodal form" as a result 
of having invested their identities in them (Cummins \& Early, 2011, p. 3). These texts thus reinforce students' identities in that they emphasize their role as active agents of their own language learning process, who are responsible for, and have ownership over, meaning-making (cf. Norton, 2010b). DTI also hold "a mirror up to students in which their identities are reflected back in a positive light" (ibid.), when learners share them with multiple audiences such as peers, teachers, and parents, who may collaborate in their creation. Students are "likely to receive positive feedback and affirmation of self in interaction with these audiences" (ibid.), which also contributes to strengthening the relationship between their experiences in and outside school, making their learning more meaningful as a result (Bernhard et al., 2006; Cummins, 2006; Cummins et al., 2005a, 2005b; Giampapa, 2010). In this study, however, students produced their DTI individually and only in English. Figure 1 illustrates an identity text created collectively by Eric Flemming, the Native Arts and Culture teacher at Sir John A. Macdonald Secondary School, and his students. It was produced as part of the Songide'ewin: Aboriginal Narratives community-engaged project conducted in that educational centre.

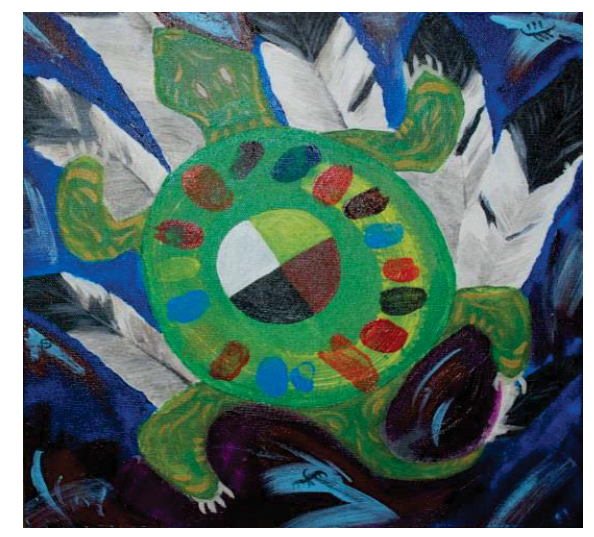

Figure. 1. Collective painting by Eric Flemming and his students within the Songide'ewin project. Source: Montero et al. (2013).

Technology in identity texts has been said to act "as an amplifier to enhance the process of identity text production and dissemination" (Cummins \& Early, 2011, p. 3). However, as discussed above, it also furnishes students' investment in their language learning, since learners find new opportunities beyond language for the creation of their texts. These enable them to reflect differently on relevant turning points in their language learning process (Darvin \& Norton, 2014), hence on their identities as language learners and by extension, on their learner identities. Therefore, learners find a space to claim greater authorial agency (Darvin \& Norton, 2014; Fong et al., 2016), gain a sense of themselves as multicompetent actors (Chen, 2013; Fong et al., 2016; Lam, 2000; Thorne \& Black, 2011; $\mathrm{Yi}, 2007$ ) and further affirm and legitimize their cultural identities when sharing their linguistic and cultural backgrounds with others (Darvin 2016; Darvin \& Norton 2014; Lam 2000; Thorne \& Black 2011; Yi 2007).

The incorporation of digital storytelling in identity texts also adds to the emergence of students' positive self-images. As suggested by Gregori-Signes and Pennock-Speck (2012, p. 5), "the concepts of agency, identity and self-expression have become the hallmark of DS". As a specific kind of DS, DTI promote learners' agency, since they become sign-makers who choose different semiotic modes for making meaning (Kress, 2003). Hence, students are producers as opposed to 
consumers of their DTI (cf. Londoño-Monroy, 2012), thus holding the power of actively controlling making, and transforming meaning. Second, as DS with a focus on identity, DTI also help learners to construct their identities in a narrative and non-essentialist manner as well as reflect upon these both in their production and reception processes (Herreros, 2012, 2013; Rodríguez-Illera y Londoño-Monroy, 2009). This is attuned to the common definition of DS as a form of selfrepresentation through media (Hull \& Nelson, 2005) and their general understanding as tools of self-expression. DTI therefore help to raise students' critical views about themselves, but also about others and social issues in as much as the " $I$ " cannot be conceived without the "you" and the context in which both are embedded (Bakhtin, in Todorov 1995). Learners' identities as socially and culturally sensitive agents are promoted in this way (Gregori-Signes, 2008, 2014; Gregori-Signes \& Pennock-Speck, 2012; Oskoz \& Elola, 2016).

In view of the above, DTI as well as non-digital identity texts help learners to consolidate their identities, empower themselves as language learners, and fuel their literacy engagement, all of which promotes the development of their multimodal and multilingual cognitive and academic language proficiency skills (Bernhard et al., 2006; Chow \& Cummins, 2003; Cummins, 2006; Cummins et al., 2005a, 2005b; Cummins \& Early, 2011; Cummins et al., 2015; Giampapa, 2010; Montero et al., 2013; etc.). School programs and projects which intend to give effective educational responses to underachievement among ELL have been employing identity texts as a tool to attain this goal, especially across Canada and the U.S. (Cummins et al., 2015). Some examples include Thornwood Elementary School near Toronto, which pioneered the application of identity texts in the English language classroom through The Dual Language Showcase project (Chow \& Cummins, 2003) ${ }^{3}$. In this project, grade1 and 2 learners from culturally and linguisticallydiverse backgrounds produced stories initially in English (the language of instruction), and later in their home languages with the aid of some multilingual teachers, parents and older learners literate in L1. They also illustrated these stories, whose visuals and text were then entered into the computer for word processing and scanning, so that they could be published on the web.

Another example is the Early Authors Program (EAP) implemented during the 2003-2004 school year in 32 child-care centres in the Miami-Dade county, Florida (US). The EAP is a large-scale literacy program which aimed to recognize Hispanic, African American and Haitian children's cultural capital and bring it to the school setting to help close the achievement gap (Bernhard et al., 2006). In this program, pre-school children produced books in English, Hispanic and HaitianCreole in collaboration with parents and teachers, who first wrote their own stories to share with one another and the children. The program was thus based on the Authors in the Classroom approach (Adda \& Campoy, 2004), which highlights the power that authorship has to develop a sense of voice and agency to ultimately change an individual's life and transform society into a more equitable and humane world. The books were produced with technology and book-making equipment in the classroom and were proved to a) enrich children's print motivation; b) increase their vocabulary; c) enhance their phonemic awareness; and, most importantly, d) promote a strong sense of self-worth and pride in cultural identity, whilst strengthening the links between and among children, their families and educators (Bernhard et al., 2008).

These examples show that underlying the use of identity texts in educational settings is "an understanding that educators must engage in authentic pedagogical practices, rooted in funds of knowledge" (Montero et al., 2013, p. 79). Funds of knowledge are bodies of knowledge and skills, culturally developed, historically accumulated and socially distributed, that are essential for the

\footnotetext{
${ }^{3}$ http://www.thornwoodps.ca/dual/
} 
functioning and well-being of an individual and a household (González et al., 2005) ${ }^{4}$. Funds of knowledge become funds of identity when speakers appropriate them and use them to define, express and understand who they are (Esteban-Guitart \& Moll, 2014; Esteban-Guitart \& Saubix, 2013). Therefore, by implementing pedagogical practices that help students use their funds of identity (e.g., through the production of identity texts), teachers can get to a better understanding of who they are as individuals and learners, whilst learners can feel that their linguistic and cultural capital is not excluded from curriculum and instruction, so that school is more strongly connected with their lives.

The use of identity texts in the EFL classroom thus allows for the exploration of students' identities as learners, especially as language learners, and their self-empowerment. These issues have been scrutinised from specific methodological perspectives like thematic narrative analysis (e.g., Montero et al., 2013), fairly common in biographical narrative research (Block, 2010; De Fina, 2015; Pavlenko, 2007). However, we believe that a combination of different methods and strategies of qualitative data analysis in addition to those within biographical narrative research, may be useful to elucidate which semiotic and discursive resources learners have access to and employ to craft their LI powerfully in and through their texts (Block, 2010; Pavlenko, 2007) and connect their learning experiences across time and contexts.

\section{Methods}

In view of the above, the research questions that guide this study are the following:

- How do EFL learners connect their different learning experiences across time and spaces in digital texts of identity (DTI) produced in this language?

- How do the connections they establish influence the manner in which they build their identities as learners?

- How do they build powerful learner identities in and through their discourses?

\section{a. Participants}

The participants in this research are 51 college students who were enrolled in a foreign language teaching course within the degree of Teacher of English in Primary Education at a Spanish university during the study. 7 are male and 44 are female between 22 and 25 years of age. They are mostly bilingual Spanish-Catalan speakers with an average B2 level of English.

The teacher is also the researcher with twenty-two years of experience in TEFL, and thirteen years of experience in second language teacher education.

\section{b. Data and data collection}

The data for this research are 51 DTI produced by these college students according to certain guidelines established by the teacher. All had learnt to produce DS in other courses within their degree. Therefore, they were familiar with the fundamental elements of DST (Lambert, 2010) and

\footnotetext{
${ }^{4}$ For an updated review of the funds of knowledge approach in education, see Llopart and Esteban-Guitart
} (2018). 
had experienced the stages of DS development (Oskoz \& Elola, 2016). Hence, they edited their DTI on their own at home, but could consult the teacher on any aspect of their DTI production and their scripts. With regards to content, learners were encouraged to explore their EFL learner identities through:

- the description of an interesting anecdote in their language learning process, a specific stage in such process, or their whole life experience as EFL learners;

- the inclusion of a dramatic question that guided their narratives and was answered throughout the story (Gregori-Signes, 2008, 2014; Robin, 2006) ${ }^{5}$;

- their depiction in light of the individual differences that affect second language acquisition (age, aptitude, motivation, anxiety, etc.)

- their description in terms of the learning styles and strategies they use in their learning and possible changes of these over time.

Concerning format, students were allowed to use any video or photo editing program they felt comfortable with to create their texts (e.g., Windows MovieMaker, Audacity, Powtoon; etc.), and their stories were limited to seven minutes duration.

Learners watched and shared their DTI along with anonymously evaluating at least one of these texts distributed by the teacher. To this end, students followed a rubric that contained the key elements of DS identified by Robin (2006) and contemplated Gregori-Signes' (2014) suggestions for their evaluation in education.

\section{c. Analysis}

Data analysis followed Coll and Falsafi's (2010, p. 219) notion of "learner identity", which "contains, connects and enables reflection over the emotional and cognitive processes of the experience of becoming and being a learner, in the past as well as in the present and the future". It also considered its two modalities, namely, Learner Identity (LI) or the permanent cross-situational identity of a learner, and Learner Identity Process (LIP) or their temporary local identity in specific learning situations. Socio-historical identities such as "native speaker" (Darvin \& Norton, 2015), "intercultural speaker" (House, 2008) and "student" (Fong et al., 2016) were also taken into account as positions learners could invoke, appropriate, transform and resist in and through their discourses. Such identities reveal the way persons are categorised according to models of identity that have long been socially constructed and acknowledged (Wortham, 2006).

However, identity building is not only done through open categorization, but also through indexical processes. Therefore, we also adopted some of Wortham's $(2004,2006)$ types of cues for data analysis, which index voices and enable interactional positioning in discourse. For instance: metapragmatic verbs, quotation, evaluative indexicals and epistemic modalization. It is our contention that examination of these indexical devices whereby learners construct their identities semiotically and discursively "offers promise for improving and enhancing learning contexts" (Norton \& Toohey, 2011, p. 415).

\footnotetext{
${ }^{5}$ Although students already knew that this was an important element to include in their DTI, the teacher found it appropriate to emphasize it explicitly in the instructions of the task.
} 
Certain principles of critical discourse analysis (CDA) were also followed in that power was assumed to permeate discourse, hence power relations are inscribed within any social exchange (Wodak \& Meyer, 2004). Additionally, in tune with poststructuralist discourse analysis (PDA), speakers in this study were perceived as agents who "can self-reflexively transform their positions through acts of negotiation, challenge, self-reflexivity, and resistance" (Baxter, 2006, p. 47).

Kress and van Leeuwen's (2006) framework was also embraced in the analysis of students' DTI in order to establish relationships between visual semiotic resources and linguistic elements therein. In particular, we followed their distinction between narrative and conceptual images, i.e., images that present "unfolding actions, events, processes of change, and transitory spatial arrangements" (Kress \& van Leeuwen, 2006, p. 59), and images that represent objects, events and participants "in terms of their generalized and more or less stable and timeless essence" respectively (ibid., p. 79).

Finally, two common types of narrative analysis in the study of identity construction and negotiation, namely, "thematic analysis", and "dialogic/performative" analysis were adopted (Block, 2010). Thematic analysis focuses on the content of what is said, whereas dialogic/performative analysis refers to whom an utterance is addressed to, when and for what purposes.

\section{Results}

With respect to the first research question, learners resorted to multiple artifacts to connect their different learning experiences across time and spaces in their DTI. We may distinguish artifacts in the production plane, in which DTI mainly amount to media products, and artifacts in the narrative plane or storytelling world, in which DTI mostly consist of stories or narratives (cf. Kress \& van Leeuwen, 2001). The former thus emphasise the material and semiotic nature of these texts, whereas the later highlight their discursive character. Artifacts in the production plane included narrative and conceptual images, short videos, and different soundtracks that students used to sustain their stories. Additionally, images and videos also contained more specific artifacts such as daily objects inside and outside households (cars, buses, bicycles, planes, backpacks, reading lamps, desks, televisions, CD-players, MP4s, headphones, computers, etc.); print and media-based materials (books, textbooks, CDs, movies, series, posters, flyers, etc.); objects that are often recognised as linguistic, political and religious symbols (flags, banners, pamphlets); and different people students related to (strangers, acquaintances, friends, family, and teachers).

Artifacts in the narrative plane consisted of certain actions, activities, and practices that students engaged in or desired (singing songs, travelling, taking exams, doing exercises, etc.), and social relationships that they had in the past, maintained in the present, or imagined in the future with significant others. Students mentioned these relationships in their stories or enacted them therein by interacting with parents, brothers, sisters, aunts, uncles, cousins and best friends (cf. GarcíaPastor, 2018). Lastly, these artifacts included students' beliefs mostly about languages, language use and actions, language learning (more specifically, EFL learning), teaching, and EFL teaching.

Therefore, learners used all these artifacts to establish connections between their different learning experiences across infancy, childhood, adolescence, and adulthood in diverse instructional and noninstructional settings. Instructional contexts mostly referred to Primary school, High school, college, language schools and private lessons. Non-instructional settings included the learner's 
home, hometown and other spaces in which they spent time with friends and family, and diverse study abroad settings (cities, villages, multiple locations like mountains, fields, lakes, football fields, etc.). The links students established across all these time periods and physical spaces mainly revealed connections between three relevant learning domains: school, family and private life and the foreign language community, which was especially significant for them as L2/FL learners.

In the following example, $A B$, a female student, describes how she had the opportunity to improve her English by going to Canada with her friend Brian and other youngsters. To this end, she uses narrative images in the production plane that contain flags, a Canada sign and a yellow bus. She also mentions her friendship with Brian in the narrative plane to connect her situated experience of learning English in this country (LIP) with her permanent cross-situational experience of learning this language or "language learning identity" (LLI) by analogy with Coll and Falsafi's (2010) LI, and Mercer's (2011) distinct self-concept for language learning:

Example (1) DTI-AB.

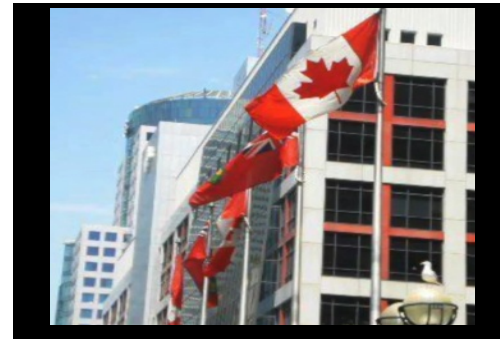

After these years I had the opportunity to go abroad to improve my English level. So I went to Canada with a group of students I didn't know. Only I knew my friend Brian.

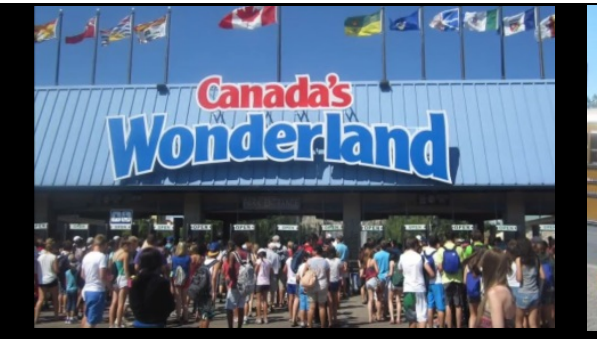

[Soundtrack playing. No narrator voice]

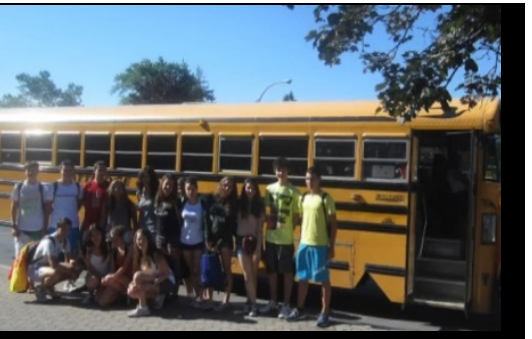

[Soundtrack playing. No narrator voice]

Students' learning experiences within the domains of the family and their private lives mainly concerned their learning of English and referred to situational practices as varied as playing computer games in English, playing guitar in one's room and composing songs in this language, going to a live concert offered by a British band, watching series and movies in English, listening to music in English, etc. All these experiences revealed the belief that language learning necessarily requires oral production, interaction and reception (Council of Europe, 2017). Oral production and interaction (i.e., speaking and spoken interaction) in the form of face-to-face communication were identified as "the best way to learn the L2/FL" (García-Pastor, 2017, p. 46). Mastery of this mode of communication was equated with native-like proficiency and learning the language in natural contexts as in first language acquisition (ibid.).

Example 2 shows the relevance of oral production and interaction for LC when she describes her early language learning experiences at a bilingual school in Santo Domingo. The school is depicted as an immersion context that led her to invest in her learning of English, so that she increased the value of her linguistic and cultural capital in this language (cf. Darvin \& Norton, 2015; Norton, 1995; Norton \& Toohey, 2011). 


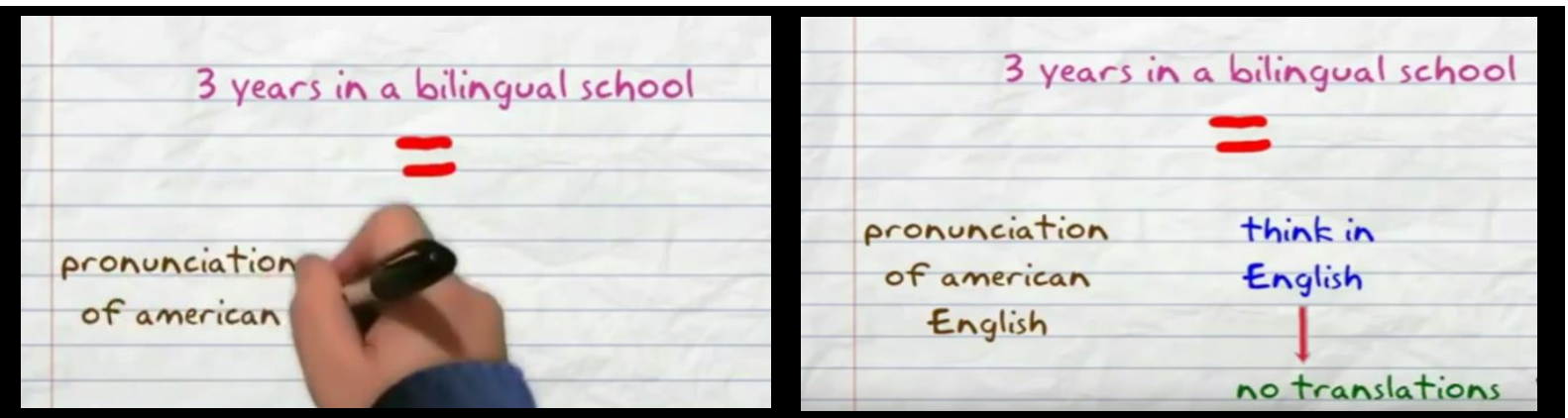

Thanks to these three years in a bilingual school with

It also made me think in English the most part of the native speakers, I acquired the real pronunciation of day, so I'm not used to do translations into Spanish. American English.

As opposed to oral production and interaction, written production and interaction were hardly mentioned. Although a few learners acknowledged their importance in the context of our technologically-based society, in general, students chiefly situated writing practices within educational contexts and associated these with grammatical exercises, exams and tests. In Example 3, NA, a female learner, links writing to learning grammar and doing multiple choice exercises by means of conceptual images of grammar textbooks, a visual complain that such practices were not motivating and an extract from one of these exercises.

Example (3) DTI-NA.

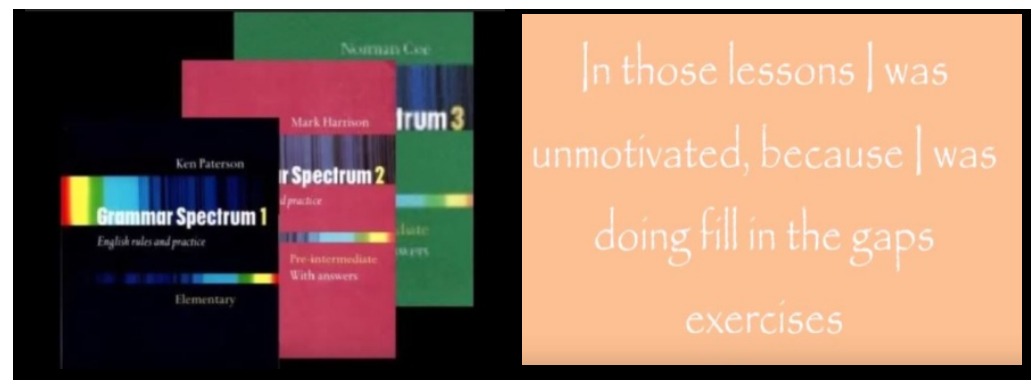

[Soundtrack playing. No narrator voice]
[Soundtrack playing. No narrator voice]

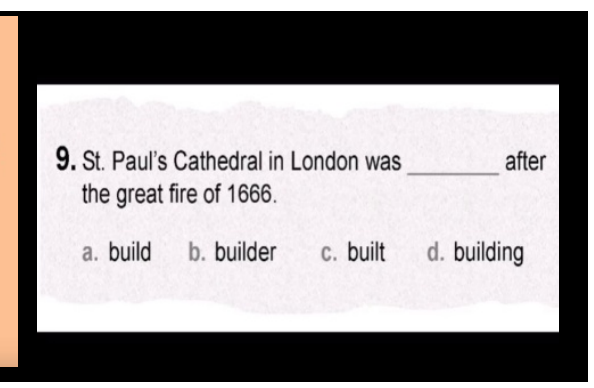

[Soundtrack playing. No narrator voice]

The previously mentioned artifacts both in the production and narrative planes, and the connections they afforded students to make between their learning experiences across time and settings constitute resources for identity construction in so far as they are elements, through which learners instantiated their narratives (De Fina, 2015; Pavlenko, 2007). Identities, in our view, live in and through discourse, since they "are always embedded and conveyed within specific storytelling practices" (De Fina, 2015, p. 365). Students thus resorted to such artifacts to categorise, and index objects, persons (including themselves), actions, relationships, and beliefs with the aim of building their identities as learners in general, and language learners in particular.

More specifically, they categorised social agents as "teacher", "native speaker", "member of a foreign community", "student", "class", "international student", etc., with regards to instructional and natural language learning contexts (cf. Darvin \& Norton, 2015; Fong et al., 2006; García- 
Pastor, 2017, 2018), and "mother", "father", "aunt", "friend", etc., concerning family and significant others. At the same time, they qualified themselves in multiple ways that rendered their LI, and LLI negatively on occasion (e.g., "anxious learner", "unmotivated learner"), but also positively when identifying with "identities of competence" (Manyak, 2004) (e.g., "intercultural speaker", "active learner", "Primary school English teacher") (García-Pastor, 2018). Through their categorisation and indexing of others' and their own subject positions, learners also instantiated their social relations, which they sometimes enacted within the storytelling world:

Example (4) DTI-AB.
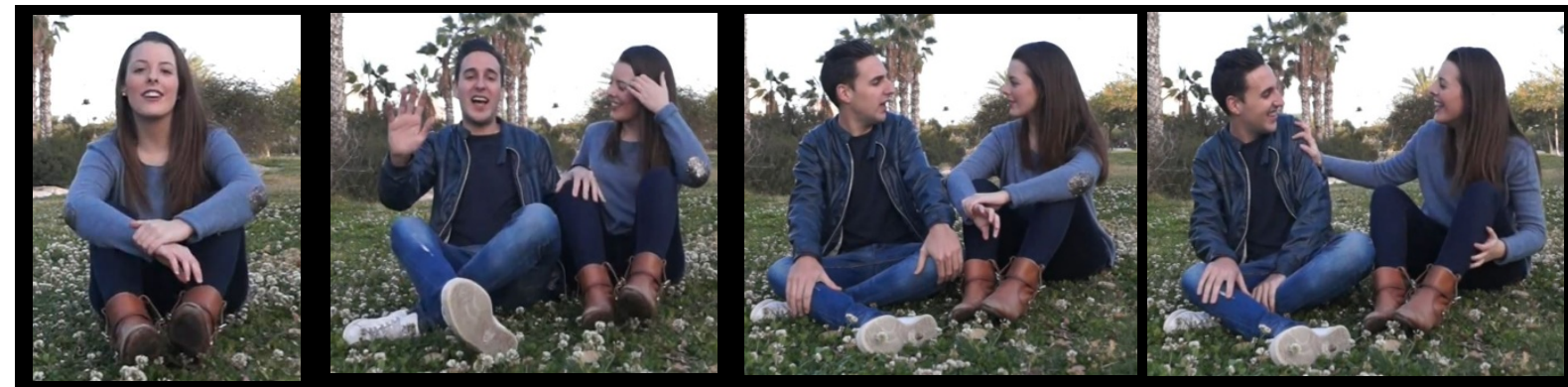

[Soundtrack playing]. My [Soundtrack playing] Hello class.

nursery friend $\mathrm{C}$ is going to help me to explain you my experience. Come here $\mathrm{C}$, say hello to my class.
[Soundtrack playing] Do you remember the first time we were in contact with English. Not really, I don't remember. No? I remember we used to play with flashcards in order to learn the colours. Ah I started to remember.
[Soundtrack playing] I used to stole them from you, and you always won. (Laughter) Because you were a cheater.

In this example, $A B$ enacts her relationship with $C$ in front of the camera, thus becoming part of the story she is narrating. In so doing, she interactively positions $C$ as her friend from nursery school, with whom she shares her first English language learning experiences. AB draws on their relational history to depict such experiences or LIP, and link them to her LI and LLI by means of epistemic modalization observed in the mental verb "remember" and the expression "used to". However, $A B$ also resorts to her relationship with $C$ to share these experiences with the audience through the evaluative statement "C is going to help me to explain you my experience", which also contains the metapragmatic verb "explain". At the same time, she categorises the audience as "class" (her classmates who will watch her DTI), and employs the evaluative indexical "cheater" to position $\mathrm{C}$ morally with respect to shared understandings of fair play. In so doing, she reflexively positions herself as a fair player, and by extension, a good student in nursery school.

Example 4 therefore illustrates not only how students integrated artifacts from the production and narrative planes in their DTI, but also how these took on a narrative shape when combined with specific images, and discursive devices and strategies (epistemic modalization, metapragmatic verbs, and evaluative indexicals). Learners used these for crafting their LI and LLI, and connecting both with their LIP. Although learners' LIP clashed at some point with their set of more generalised meanings about themselves as learners (LI), and language learners (LLI), these experiences ended up cohering with the latter, thus contributing to reify students' positive LI and LLI, and promote their perception of these as stable constructs (Coll \& Falsafi, 2010; De Fina, 2015; Esteban-Guitart 
\& Moll, 2014). From the perspective of discourse genres, such clashes mainly correspond with problematic episodes in the story, which conveyed "some disruption of usuality" (Rothery \& Stenglin, 2005, p. 233), and involved students' lack of recognition of themselves as the learners they perceive they are. Learners solved such problems, hence maintained the coherence and continuity of their LI and LLI, mainly through descriptions and accounts of different kinds.

In Example 5, LM was disappointed at the beginning of her stay with a family in England, because she could not understand them. Therefore, LM's motive for remaining there, namely, improving her English, did not match the learning situation she found herself in at first, since she was confused in spite of her fair command of English. This temporarily impeded her attribution of meaning to her study abroad, and consequently threatened her self-recognition as EFL learner. LM'S LI and LLI finally attains a sense of coherence as revealed through her depiction of her gradual improvement, and the relevance of the whole experience for learning other languages and travelling in the future.

Example (5) DTI-LM.

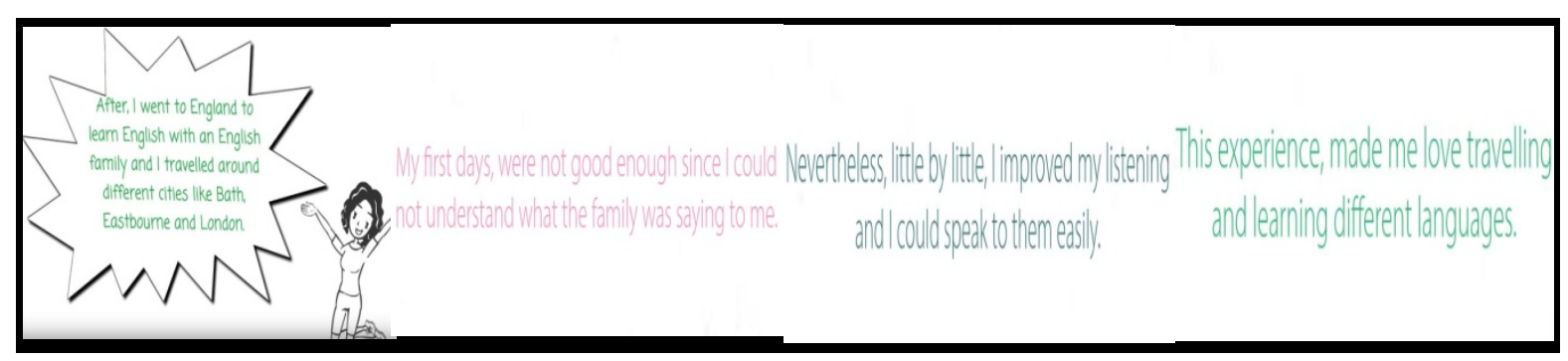

[Soundtrack playing] [Soundtrack playing] [Soundtrack playing] [Soundtrack playing]

As established in our second research question, students' links between their different learning experiences influenced the manner in which they built their LI and LLI in and through their DTI in different ways. Thus, learners who had been through difficult learning situations and had been unable to overcome these were not prepared to invest in their language learning. As a result, they constructed an image of themselves as conservative learners as opposed to risk takers. For example, in a DTI produced by DH, a male student, he narrates how he began to have a bad experience learning English when he turned seventeen. The pressure of achieving good grades to access higher education, the boring and repetitive English lessons he was attending to in High school, and his increasing feeling of anxiety and dislike for this language culminated in him failing an official advanced English exam and quitting learning the language for four years. DH therefore accepts the silencing identities that derived from his failure, characterising himself as a student with low self-esteem and self-confidence, unwilling to invest in his language learning (cf. Coll \& Falsafi, 2010; Menard-Warwick, 2007; Norton, 1995, 2013, 2014).

Conversely, learners who had been through complex learning circumstances and had been able to cope successfully, constructed their identities as competent and secure learners, determined to continue learning. The majority of students in this research cast their LI and LLI in this light. In her DTI, HV, a female student, tells us how she was able to compensate for her lack of linguistic competence in German, when she enrolled in a German school during her childhood. Teachers were native speakers of German and only addressed pupils in this language. HV describes how she resisted the silencing identity that she was ascribed due to her poor command of the language, and her struggle to increase the value of her linguistic and cultural capital therein (cf. Lam, 2000; 
Mernard-Warwick, 2007; Norton, 1995, 2013, 2014). In the end, she explains how claiming an identity of "German speaker" helped her to craft her LI and LLI as a "good language learner" (see Coll \& Falsafi, 2010) and continue investing in her learning of this language and other foreign languages like English.

In general, the connections students established between their different LIP conflated in an image of themselves as autonomous, active and competent learners, capable of overcoming difficult learning circumstances, adjusting to new learning situations and investing in their English language learning (Cummins et al. 2005b, Cummins et al. 2015; Norton \& Toohey, 2011). This LI and LLI mostly rests on students' links between their experiences with English at home and in their daily lives (e.g., reading books in English, watching movies and series in this language, going to a live concert, etc.); those in certain educational settings, mostly bilingual schools, language schools and Primary school classrooms (e.g., playing games in English, using English to learn other subjects, etc.); and those in study abroad contexts (e.g., going on fieldtrips, cooking, etc., with other international students). Learners used their homes and other everyday settings to improve reception in English (i.e., reading and listening), and specific educational contexts and study abroad periods to put all their linguistic knowledge to use, especially through spoken interaction and mediation (cf. Council of Europe, 2017). Therefore, students' connections between all these learning experiences in these different contexts, led them to perceive such settings as valuable learning spaces that reinforced positive learning experiences from school, counteracted negative ones, and contributed to their construction of powerful identities as learners in general, and EFL learners in particular.

Such powerful LI and LLI epitomised in the position of "intercultural speaker", through which an individual is attributed knowledge of languages and cultures different from their own, an ability to develop an attitude deprived of ethnocentrism, and a capacity to mediate between such languages and cultures and reframe their own identity in intercultural encounters (García-Pastor, 2018; House, 2008). In other words, endorsing this subject position amounted to perceiving oneself as a "mediator between languages and cultures, and a citizen of the world" (García-Pastor, 2017, p. 53). It also entailed rejecting the ideal native speaker model against which mastery of English is commonly measured, and acknowledging a diverse English-speaking world, in which the view of the language learner as a real and legitimate language user is emphasised. Learners therefore advocated public projections versus policy-driven projections of language and language learning (Dewey \& Long, 2010), which counterbalanced their a priori ascribed lack of power as language learners.

Learners built such position in and through their DTI by describing their learning experiences abroad and referring to their role of mediators in such intercultural exchanges. In so doing, they frequently deployed narrative images, which underscored their personal involvement in the experiences they were narrating; they drew on social relationships and persons they met in these exchanges; and they used evaluative indexicals based on positive terms and expressions. In Example 6, AG depicts her learning experience in Norway, and builds her identity as an intercultural speaker by indicating how she developed her social skills in mediating between students from different countries, and learning to cook meals from other cultures. She also resorts to positive evaluative indexicals to reinforce such identity, and render it powerful and ongoing ("amazing", "improve", "very good friends which I'm still in contact"). 
Example (6) DTI-AG.
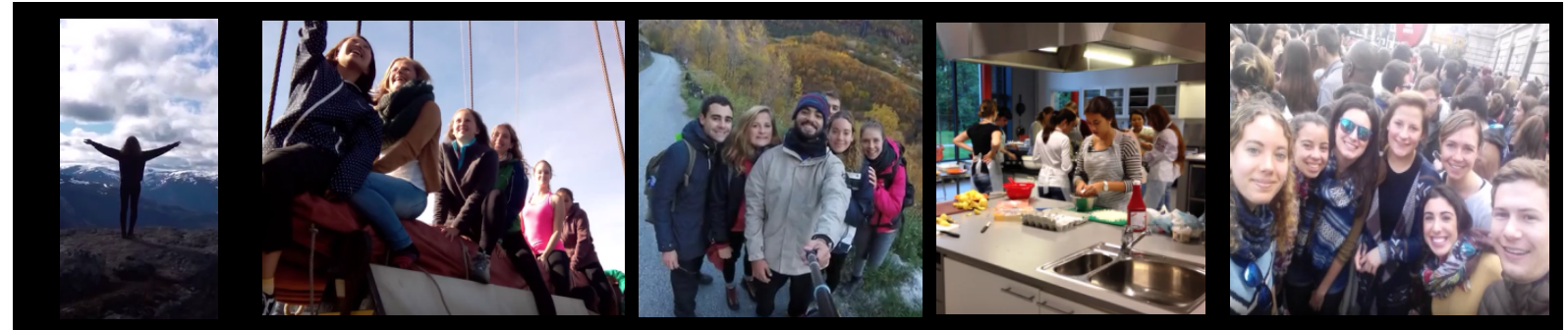

[Soundtrack playing]

"... and I

managed to go to Norway, where I spent these five last months.
[Soundtrack playing] It was an amazing experience which allowed me not only to improve my English level, but also to develop other skills [...]
[Soundtrack playing]

I met a lot of people from different countries which allowed me to develop and improve my social skills.
[Soundtrack playing] I learnt to cook food from other cultures.
[Soundtrack playing] I met very good friends which I'm still in contact.

Students also constructed powerful LI and LLI by means of authority claims, which amount to quoting or invoking others' voices in one's discourse, and, in general, by enhancing the "self as author" aspect of their discoursal selves or "a writer's relative authoritativeness" (Ivanič, 1998, p. 23), which foregrounds the writer's authorial agency. Authority claims mainly consisted of statements about foreign language learning and teaching issued by authority figures in the field of second language acquisition and language education. Students appropriated or challenged such claims either without explicitly indicating the source, or quoting it directly. Learners thus exhibited mastery of specific theoretical concepts and issues, which involved the use of specialised jargon, and contributed to presenting them as knowledgeable individuals (Menard-Warwick, 2007). Hence, they challenged their ascribed a priori powerless position of EFL learners and students in a foreign language teaching course. In Example 7, JP, a male student, accrues power in and through his DS by explicitly invoking Krashen and challenging his views verbally mostly through narrative images.

Example (7) DTI-JP.

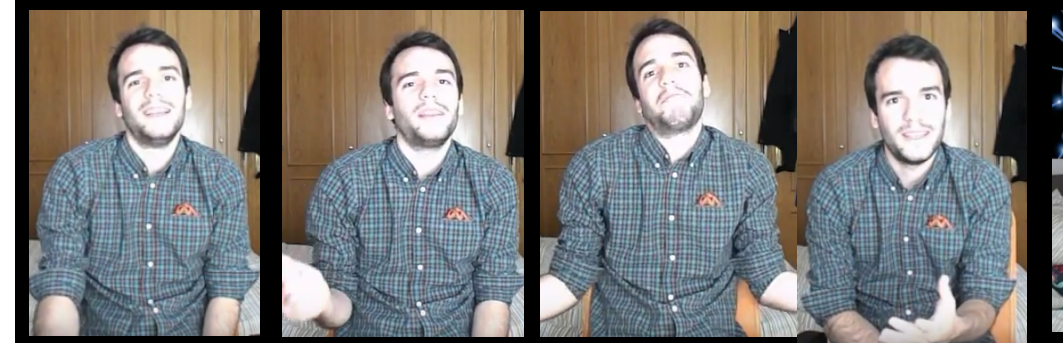

[...] because like the opposite of Krashen says that...eh she says, well he says...eh just eh the learner has to listen for a while and then he would start talking.
I don't think that it's true (laughs), because a learner needs to try some output eeh to to realise and then to realise if he or she is able to communicate it

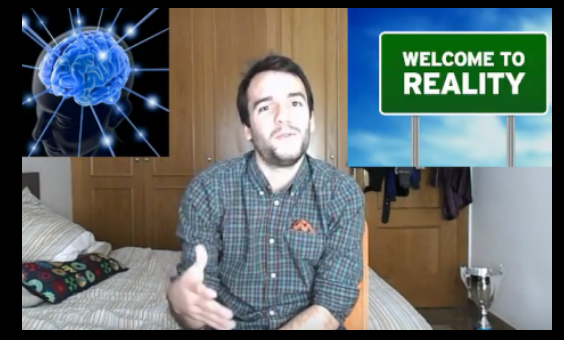

because one thing is what you have it in your mind and another thing very different is what you're able to say. 
what is in his

or her mind

Learners also built powerful LI and LLI by engaging in certain semiotic and discursive practices that have typically been recognised as authoritative; for instance, the use of their voices to narrate their stories, which denotes ownership over these. According to Norton (2010b, p. 1), this sense of ownership over meaning making can help students to "have enhanced identities as learners and participate more actively in literacy practices". Ascribing a print-based format to their texts visually and discursively was another strategy students employed to cast their LI and LLI more powerful. Some DTI thus adopted the shape of a blackboard or whiteboard in which learners wrote and draw their stories, or a book divided into chapters the student writer read to the audience, which reveals learners' beliefs on the power of text-based literacy over other forms of literacy in the context of Higher education (cf. Hull \& Nelson, 2005). Finally, some learners also uttered self-assuring statements, which were often accompanied by narrative images illustrating their high self-worth; for example, "I know who I am, what I like, and what I'm good at" by HV.

\section{v. Conclusions}

This study has examined how EFL learners within a foreign language teaching course at a Spanish university establish connections between their learning experiences across time and settings in digital texts of identity produced in this language. It has also inquired how such connections shape their identities as learners and language learners, and how these students get to build powerful learner identities in and through their discourses. Drawing on different resources, strategies, and methods for qualitative data analysis, especially in identity and biographical narrative research, this study shows that students accessed and employed multiple artifacts both in the production and narrative story planes to link their learning experiences across their life span in the domains of the family and their daily lives, school and the foreign language community. In so doing, they aimed to a) convey a coherent LI and LLI in spite of some LIP that challenged such coherence, and b) reinforce and enhance these identities so as to endow them with power.

Artifacts in the production plane included narrative and conceptual images, videos, and music, with the first two also encompassing more specific artifacts such as different kinds of objects, people, relationships, and beliefs, especially with regards to languages, language use and actions, and EFL learning and teaching. It has been argued that these artifacts are semiotic and discursive devices for identity construction to the extent that they are resources learners use to instantiate their narratives, since identity can only be enacted in and through storytelling practices. Therefore, such artifacts took on a narrative shape when combined with specific images and discursive resources (i.e., epistemic modalization, metapragmatic verbs, and evaluative indexicals), enabling students to construct their LI, LLI and LIP. Students' connections of their LIP with the former were not unproblematic, since some learners reported difficult learning experiences at some point, which threatened their self-recognition as good learners, hence their attainment of "identities of competence" (Manyak, 2004). Others, however, went through opposite experiences by successfully managing such problematic situations and asserting their positive LI and LLI as a result.

Nevertheless, the majority of learners in this study achieved cohesive personas, and highlighted their positive experiences and their success in their learning of English. Students mainly 
understood such learning in terms of reception, oral production and interaction, and mediation. Learners linked reception to their home and private lives, whereas they mostly related oral interaction and mediation to certain educational settings and study abroad contexts. By contrast, written production and interaction were disregarded as relevant modes of developing proficiency in $\mathrm{EFL}$, and were primarily associated with paper-and-pencil literacy practices such as grammatical exercises, exams and tests at school. When related to writing texts, these practices were deemed authoritative in college education and learners embraced them in their DTI as a way of subverting their powerlessness as learners. These considerations may provide EFL teachers with useful information for the design and implementation of pedagogical practices that instil a broader view of literacy in students, which considers the digital in and outside the classroom and promotes a more positive view of written production and interaction in the target language.

Learners in this study also used authority claims and other devices such as their own voices and self-assuring statements to empower themselves. All in all, these practices illustrate students' claims of the right to speak and have a "voice" in the target language. These findings therefore support the view of identity texts as a valuable pedagogical tool that fosters the construction of powerful learner identities and contributes to narrowing the gap between family, school and other relevant domains in a learner's life.

\section{Acknowledgments}

I am greatly indebted to the learners in this study, who kindly granted their permission to reproduce the images in their texts. I would also like to express my gratitude to the editors of this journal issue, the reviewers of this paper, and Ronan Miller for their valuable comments on an earlier version of this paper.

\section{References}

Adda, A. F., \& Campoy, F. I. (2004). Authors in the classroom: A transformative education process. Boston, MA: Pearson.

Baxter, J. (2016). Positioning language and identity: Poststructuralist perspectives. En S. Preece (Ed.), The Routledge handbook of language and identity (pp. 34-49). London: Routledge.

Bernhard, J. K. et al. (2006). Identity texts and literacy development among preschool English language learners: Enhancing learning opportunities for children at risk for learning disabilities. Teachers College Record, 108(11), 2380-2405. Retrieved from http://www.tcrecord.org/content. asp?contentid=12809

Bernhard, J. K. et al. (2008). "Read my story!" Using the Early Authors Program to promote early literacy among diverse, urban preschool children in poverty. Journal of Education for Students Placed at Risk, 13, 76-105. doi: 10.1080/10824660701860458

Block, D. (2010). Researching language and identity. In B. Paltridge \& A. Phakti (Eds.), Continuum companion to research methods in applied linguistics (pp. 337-347). London: Continuum.

Block, D. (2013). Issues in language and identity research in applied linguistics. ELIA, 13, 11-46. doi: http://dx.doi.org/10.12795/elia.2013.i13.01

Chapelle, C. A., \& Heift, T. (2009). Individual learner differences in CALL: The field independence/dependence (FID) construct. CALICO Journal, 26(2), 246-266. doi:10.1558/cj.v26i2.246-266

Chen, H-I. (2013). Identity practices of multilingual writers in social networking spaces. Language Learning \& Technology, 17(2), 143-170. Retrieved from http://It.msu.edu/issues/june2013/chen.pdf 
Chow, P., \& Cummins, J. (2003). Valuing multilingual and multicultural approaches to learning. In S. R. Schecter \& J. Cummins (Eds.), Multilingual education in practice: Using diversity as a resource (pp. 32-61). Portsmouth, NH: Heinemann.

Coll, C., \& Falsafi, L. (2010). Learner identity: An educational and analytical tool. Revista de Educación, 35(3), 211-233. Retrieved from www.revistaeducacion.educacion.es/re353/re353_08.pdf

Cope, B., \& Kalantzis, M. (2015). A pedagogy of multiliteracies: Learning by design. London: Palgrave.

Council of Europe (2017). Common European Framework of Reference for Languages: Learning, Teaching, assessment. Companion volume with new descriptors. [Accessed: 20/10/2017]. Retrieved from: https://rm.coe.int/common-european-framework-of-reference-for-languages-learningteaching/168074a4e2

Cummins, J. (2006). Identity texts: The imaginative construction of self through multiliteracies pedagogy. En O. García et al. (Eds.), Imagining multilingual schools: Language in education and glocalization (pp. 5168). Clevedon: Multilingual Matters.

Cummins, J., \& Early, M. (2011). Identity texts: The collaborative creation of power in multilingual schools. UK: Trenthan Books.

Cummins, J. et al. (2005a). ELL students speak for themselves: Identity texts and literacy engagement in multilingual classrooms [Accessed: 07/06/2016]. Retrieved from: http://www.curriculum.org/secretariat/files/ELLidentityTexts.pdf

Cummins, J. et al. (2005b). Affirming identity in multilingual classrooms. Educational Leadership, 63(1), 38-43. Retrieved from http://www.ascd.org/publications/educationalleadership/sept05/vol63/num01/Affirming-Identity-in-Multilingual-Classrooms.aspx

Cummins, J. et al. (2015). Identity texts and academic achievement: Connecting the dots in multilingual school settings. TESOL Quarterly, 49(3), 555-581. doi: https://doi.org/10.1002/tesq.241

Darvin, R. (2016). Language and identity in the digital age. In S. Preece (Ed.), The Routledge handbook of language and identity (pp. 523-539). London: Routledge.

Darvin, R., \& Norton, B. (2014). Transnational identity and migrant language learners: The promise of digital storytelling. Education Matters, 2, $\quad$ 55-66. http://faculty.educ.ubc.ca/norton/Darvin\%20and\%20Norton. \%202014.\%20Transnational\%20identity\% 20and\%20migrant\%20language\%20learners.pdf

Darvin, R., \& Norton, B. (2015). Identity and a model of investment in applied linguistics. Annual Review of Applied Linguistics, 35, 36-56. doi: 10.1017/S0267190514000191

De Fina, A. (2015). Narrative and identities. In A. De Fina \& A. Georgakopoulou (Eds.), The Handbook of narrative analysis (pp. 351-368). Malden, MA: Wiley Blackwell.

Dewey. M., \& Leung, C. (2010). English in English language teaching: Shifting values and assumptions in changing circumstances. Working Papers in Educational Linguistics, 25(1), 1-15. Retrieved from https://repository.upenn.edu/wpel/vol25/iss1/1/

Dörnyei, Z. (2009). The L2 motivational self system. In Z. Dörnyei \& E. Ushioda (Eds.), Motivation, language identity, and the L2 self (pp. 9-42). Clevedon: Multilingual Matters.

Esteban-Guitart, M., \& Moll, L. (2014). Funds of identity: A new concept based on the funds of knowledge approach. Culture \& Psychology, 20(1), 31-48. doi: 10.1177/1354067X13515934

Esteban-Guitart, M., \& Saubix, X. (2013). La práctica educativa desde la perspectiva de los fondos de conocimiento e identidad. Teoría de la Educación, 25(2), 189-211. Retrieved from http://revistas.usal.es/index.php/1130-3743/article/view/11583

Esteban-Guitart, M. et al. (Eds.) (forthcoming). Learning across settings and time in the digital age, Digital Education Review (special issue). http://revistes.ub.edu/index.php/der 
Fong, C. J. et al. (2016). Positioning identity in computer-mediated discourse among ESOL learners. Language Learning \& Technology, 20, 142-158. Retrieved from http://llt.msu.edu/issues/october2016/fonglinengle.pdf

García-Pastor. (2017). Learners' identities at stake: Digital identity texts in the EFL classroom. Language Value, 9(1), 36-61. Retrieved from http://www.languagevalue.uji.es/index.php/languagevalue/article/view/125

García-Pastor. (2018). Textos de identidad digitales: Una valiosa herramienta para el estudio de la construcción de la identidad y el aprendizaje lingüístico en ILE. Signos, 50, 24-44. Retrieved from http://www.revistasignos.cl/index.php/signos/article/view/140/59

Giampapa, F. (2010). Multiliteracies, pedagogy and identities: Teacher and student voices from a Toronto Elementary school. Canadian Journal of Education, 33(2), 407-431. Retrieved from http://www.jstor.org/stable/canajeducrevucan.33.2.407

González, N. et al. (2005). Funds of knowledge: Theorizing practices in households, communities, and classrooms. Mahwah, NJ: Lawrence Erlbaum.

González-Lloret, M., \& Ortega, L. (2014). Towards technology-mediated TBLT: An introduction. In M. GonzálezLloret \& L. Ortega (Eds.), Technology-mediated TBLT: Researching technology and tasks (pp. 1-22). Amsterdam: John Benjamins.

Gregori-Signes, C. (2008). Integrating the old and the new: Digital storytelling in the EFL classroom. GRETA Journal, 16, 43-49. Retrieved from http://www.citeulike.org/user/acadlit/article/7218020

Gregori-Signes, C. (2014). Digital Storytelling and multimodal literacy in education. Porta Linguarum, 22, 237$250 . \quad$ Retrieved from http://www.ugr.es/ portalin/articulos/PL_numero22/16\%20\%20Carmen\%20Gregori.pdf

Gregori-Signes, C., \& Pennock-Speck, B. (2012). Digital storytelling as a genre of mediatized selfrepresentations: An introduction. Digital Education Review, 22, 1-8. [Accessed: 12/10/2016]. Retrieved from: http://greav.ub.edu/der

Herreros, M. (2012). El uso educativo de los relatos digitales personales como herramienta para pensar el Yo (Self). Digital Education Review, 22, 68-79. [Accessed: 30/04/2018]. Retrieved from: http://greav.ub.edu/der

Herreros, M. (2013). Reflexión sobre la enseñanza aprendizaje de los relatos digitales personales en el bachillerato a través de EVEA y Web 2.0. In C. Gregori-Signes \& M. Alcantud-Díaz (Eds.), Experiencias con el relato digital (E-reader version). Valencia: JPM Ediciones. Retrieved from http://www.jpmediciones.es/

House, J. (2008). What is an 'intercultural speaker'?. In E. Alcón Soler \& M. P. Safont Jordá (Eds.), Intercultural language use and language learning (pp. 7-21). New York: Springer.

Hull, G. A., \& Nelson, M. E. (2005). Locating the semiotic power of multimodality. Written Communication, 22(2), 224-261. doi: 10.1177/0741088304274170

Ivanič, R. (1998). Writing and identity: The Discoursal construction of identity in academic writing. Amsterdam: John Benjamins.

Jin, L. (2013). Language development and scaffolding in a sino-american telecollaborative project. Language Learning \& Technology, 17(2), 193-219. Retrieved from http://It.msu.edu/issues/june2013/jin.pdf

Jones, R. H., \& Hafner, C. A. (2012). Understanding digital literacies: A practical introduction. London: Routledge.

Klimanova, L., \& Dembovskaya, S. (2013). L2 identity, discourse, and social networking in Russian. Language Learning \& Technology, 17(1), 69-88. Retrieved from http://llt.msu.edu/issues/february2013/klimanovadembovskaya.pdf

Krashen, S. (1982). Principles and practice in second language acquisition. New York: Pergamon Press. 
Kress, G. (2003). Literacy in the new media age. London: Routledge

Kress G., \& van Leeuwen, T. (2001). Multimodal discourse: The modes and media of media of contemporary communication. London: Arnold.

Kress, G. and van Leeuwen, T. (2006). Reading images: The grammar of visual design. London: Routledge.

Lam, W. S. E. (2000). L2 literacy and the design of the self: A case study of a teenager writing on the Internet. TESOL Quarterly, 34(3), 457-482. doi: 10.2307/3587739

Lambert, J. (2010). Digital storytelling cookbook. Berkeley, CA: Center for Digital Storytelling.

Little, D., \& Erickson, G. (2015). Learner identity, learner agency, and the assessment of language proficiency: Some reflections prompted by the Common European Framework of Reference for Languages. Annual Review of Applied Linguistics, 35, 120-139. doi: 10.1017/S0267190514000300

Londoño-Monroy, G. (2012). Aprendiendo en el aula: contando y haciendo relatos digitales personales. Digital Education Review, 22, 19-36. [Accessed: 30/04/2018]. Retrieved from http://greav.ub.edu/der

Llopart, M., \& Esteban-Guitart, M. (2018). Funds of knowledge in 21st century societies: inclusive educational practices for underrepresented students. A literature review. Journal of Curriculum Studies, 50(2), 145161. doi: https://doi.org/10.1080/00220272.2016.1247913

Mackey, A. (2015). Identity in applied linguistics. Annual Review of Applied Linguistics, 35, 1-273. doi: https://doi.org/10.1017/S026719051500001X

Manyak, P. C. (2004). 'What did she say?' Translation in a primary-grade English immersion class. Multicultural Perspectives, 6, 12-18. doi: https://doi.org/10.1207/S15327892mcp0601_3

Menard-Warwick, J. (2007). 'Because she made beds. Every day'. Social positioning, classroom discourse, and language learning. Applied Linguistics, 29(2), 267-289. doi:10.1093/applin/amm053

Mercer, S. (2011). Towards an understanding of language learner self-concept. New York: Springer.

Mercer, S. (2014). The self from a complexity perspective. In S. Mercer \& M. Williams (Eds.), Multiple perspectives on the self in SLA (pp. 160-176). Bristol: Multilingual Matters.

Montero, M. K. et al. (2013). Activist literacies: Validating aboriginality through visual and literary identity texts. Journal of Language and Literacy Education, 9(1), 73-94. [Accessed: 02/0/2018]. Retrieved from: http://jolle.coe.uga.edu/wp-content/uploads/2013/06/Validating-Aboriginality.pdf

Norton, B. (1995). Social identity, investment and language learning. TESOL Quarterly, 29(1), 9-31. doi: $10.2307 / 3587803$

Norton, B. (2010a). Language and identity. In N. Hornberger \& S. McKay (Eds.), Sociolinguistics and language education (349-369). Bristol: Multilingual Matters.

Norton, B. (2010b). Identity, literacy, and English-language teaching. TESL Canada Journal, 28(1), 1-13. doi: https://doi.org/10.18806/tesl.v28i1.1057

Norton, B. (2013). Identity and language learning: Extending the conversation (2nd ed.). Bristol: Multilingual Matters.

Norton, B. (2014). Identity and poststructuralist theory in SLA. In S. Mercer \& M. Williams (Eds.), Multiple perspectives on the self in SLA (pp. 59-74). Bristol: Multilingual Matters.

Norton, B., \& Toohey, K. (2011). Identity, language learning, and social change. Language Teaching, 44(4), 412-446. doi:10.1017/S0261444811000309

Oskoz, A., \& Elola, I. (2016). Digital stories: Overview. CALICO Journal, 33(2), 157-173. doi: $10.1558 /$ cj.v33i2.29295

Pavlenko, A. (2007). Autobiographic narratives as data in applied linguistics. Applied Linguistics, 28(2): 163188. doi:10.1093/applin/amm008 
Preece, S. (2016). The Routledge handbook of language and identity. London: Routledge.

Robin, B. R. (2006). The educational uses of digital storytelling [Accessed 05/03/2012]. Retrieved from: https://dsresources.pbworks.com/f/Educaional-Uses-DS.pdf

Rodríguez-Illera, J. L., \& Londoño-Monroy, G. (2009). Los relatos digitales y su interés educativo. Educação, Formação \& Tecnologias, 2(1), 5-18. Retrieved from http://eft.educom.pt

Rosen, L. D. (2010). Rewired: understanding the iGeneration and the way they learn (1st ed.). New York: Palgrave Macmillan.

Rothery, J., \& Stenglin, M. (2005). Entertaining and instructing: Exploring experience through story. In C. Frances \& J. R. Martin (Eds.), Genre and institutions: Social processes in the workplace and school (pp. 231-263). London: Continuum.

Swain, M. (1993). The output hypothesis: Just speaking and writing aren't enough. Canadian Modern Language Review, 50, 158-164. doi: 10.3138/cmlr.50.1.158

Thorne, S. L., \& Black, R. (2007). Language and literacy development in computer-mediated contexts and communities. Annual Review of Applied Linguistics, 27, 133-160. doi: 10.1017/S0267190508070074

Thorne, S. L., \& Black, R. (2011). Identity and interaction in internet mediated contexts. In C. Higgins (Ed.), Identity formation in globalizing contexts: Language learning in the new millennium, vol. 1 (257-278). Berlin: De Gruyter.

Thorne, S. L. et al. (2015). Technologies, identities, and expressive activity. Annual Review of Applied Linguistics, 35, 215-233. doi: 10.1017/S0267190514000257

Todorov, T. (1995). Mikhail Bakhtin: The dialogical principle. Minneapolis: University of Minnesota Press.

Wenger, E. (1998). Communities of practice. Learning, meaning and identity. New York: Cambridge University Press.

Wodak, R., \& Meyer, M. (2004). Methods for critical discourse analysis. London: Sage.

Wortham, S. (2004). From good student to outcast: The emergence of a classroom identity. Ethos, 32(1), 164187. Retrieved from http://repository.upenn.edu/gse_pubs/49

Wortham, S. (2006). Learning identity: The joined local emergence of social identification and academic learning. Cambridge: Cambridge University Press.

Yi, Y. (2007). Engaging literacy: A biliterate students' composing practices beyond school. Journal of Second Language Writing, 16, 23-39. doi:10.1016/j.jslw.2007.03.001

Zhao, Y. (2003). Recent developments in technology and language learning: A literature review and metaanalysis. CALICO Journal, 21(1), 7-27. doi: 10.1558/cj.v21i1.7-27 